Mimo powyższych zastrzeżeń, omawiane opracowanie stanowi niewątpliwie cenną i ciekawą (ze względu na ich nietypowość) analizę źródeł do badania dziejów oświaty i wychowania w dwudziestoleciu międzywojennym, i jako taka może być polecona historykom, pedagogom, historykom wychowania, jak również wszystkim osobom interesującym się historią II Rzeczypospolitej.

Magdalena Lewicka

\title{
Ks. Adam Orczyk, Zarys historii szkolnictwa i myśli pedagogicznej, Wydaw- nictwo Akademickie ,Żak”, Warszawa 2008, ss. 359
}

DOI: $10.14746 /$ BHW.2014.31.16

Pisanie podręcznika, który jest syntezą określonej dziedziny wiedzy, stanowi wielkie wyzwanie dla autora. Aby na nie w pełni odpowiedzieć, trzeba zrealizować kilka warunków, do których należą przede wszystkim przygotowanie merytoryczne i metodyczne. Nie da się tego osiągnąć bez bogatego doświadczenia dydaktycznego. Podręcznik bowiem w określony sposób kształtuje osobowość czytelnik, a więc powinien spełnić również kryteria psychorozwojowe.

Ukazanie się kolejnego podręcznika do historii wychowania jest wydarzeniem ważnym pod każdym względem. Mowa tu o Zarysie historii szkolnictwa i myśli pedagogicznej A. Orczyka. To drugi podręcznik z tej dziedziny opublikowany przez Wydawnictwo Akademickie „ZZak” po 1989 r. Jego Autor względnie dość poprawnie zaplanował, i co najważniejsze, przedstawił na 359 kartach (22,5 arkuszy drukarskich) w miarę pełny zarys historii wychowania. W odróżnieniu od innych podręczników wydanych po 1989 r., ten jest bardzo dobrze skonstruowany. Wszystko ma logiczne powiązanie i uzasadnienie, utrzymane jest w wyważonej proporcji treści do faktów i problemów, co niewątpliwie podnosi zalety podręcznika. Niekiedy są prezentowane szczegóły, które będąc ukonkretnieniem narracji, stanowią jednocześnie podstawę do ewentualnego bliższego zainteresowania się określoną problematyką. Autor wykazał się znaczną dyscypliną słowną, terminologiczną. Gdy trzeba było zaznaczyć odmienność, nie unikał tego (np. s. 74). Reprezentatywność kierunków, prądów w pedagogice nowej szkoły i nowego wychowywania jest właściwa. Ujął bowiem najważniejsze idee oraz ich przedstawicieli. To samo dotyczy współczesnych teorii i nurtów wychowania. Starał się również uwzględnić „wielką nieobecną” w dziejach wychowania. Mowa tu o pedagogice religijnej, którą w różnym stopniu eliminowano lub pomniejszano. Dzięki temu nastąpiło pewne zrównoważenie treści i pomniejszenie skrajnie subiektywnych interpretacji historii wychowania. W dużym stopniu uwzględnił pozycje obcojęzyczne oraz wykorzystał niektóre źródła i najważniejsze szczegółowe opracowania w języku polskim. Tym samym uwzględnił ważne kryterium, jakim jest zgodność osiągnięć nauki z nauczaniem przez bezpośrednią 
ich prezentację. W zasadniczych rysach oceniana publikacja spełnia postulat podręcznika kształcącego i wychowującego.

Struktura podręcznika jest wyjątkowo prosta, przejrzysta, konkretna, racjonalna. Składa się ze Wstępu, 22 rozdziałów oraz Bibliografii. Tradycyjnie więc podręcznik rozpoczyna się od prezentacji wychowania greckiego. Pominięto tu wkład państw wschodnich, starożytnych cywilizacji orientalnych. Niektóre rozdziały można było połączyć, jak na przykład „Szkolnictwo wczesnego średniowiecza i Renesans karoliński”. Owo „odrodzenie” było bowiem częścią wczesnego średniowiecza, aczkolwiek stanowiło wyodrębniający się okres w ramach uniwersalnej monarchii karolińskiej. Podobnie można było połączyć krótki rozdział „Rewolucja naukowa XVII w.” z następnym, zatytułowanym „W poszukiwaniu metody nauczania”. W kontekście analizy przedmiotowych treści rodzi się pytanie czy pedagogika pozytywizmu nie jest w większym stopniu tożsama z rewolucją przemysłową niż romantyzm. Uważam, że stosunkowo skromnie ujęto pedagogikę pozytywizmu. Rzecz ciekawa, nie poświęcono żadnego rozdziału konkretnemu reprezentantowi dziejów wychowania. Są oni zawsze podporządkowani ujęciu ogólniejszemu. To rozwiązanie bardzo dobre, pokazuje bowiem rolę i miejsce, ale również znaczenie danej koncepcji czy systemu pedagogicznego na szerszym tle i sprzyja efektywniejszemu kształceniu.

Niektóre rozdziały skłaniają do dyskusji. Rozdział „W poszukiwaniu metody nauczania" nie jest w pełni adekwatny do zawartych w nim treści. J. A. Komeński i J. Locke zajmowali się również szeroko rozumianym wychowaniem. Lepiej więc byłoby dodać do tego tytułu jeszcze słowo wychowanie. Z kolei rozdział „Reforma szkolnictwa polskiego w XVIII w. - Komisja Edukacji Narodowej (1773-1794)” nie uwzględnia w tytule działalności S. Konarskiego, co znajduje się w treści. Bardziej adekwatny byłby więc tytuł tego rozdziału bez swej drugiej części, akcentującej KEN. W rozdziale XIX nie uwzględniono niektórych ciekawych rozwiązań organizacyjnych, jak chociażby planu daltońskiego, który znalazł uznanie w Polsce okresu międzywojennego. Było to rozwiązanie nowe, wymagające tylko środków finansowych i odpowiednich nauczycieli. Słusznie jednak Autor nadał tytuł temu rozdziałowi, konkretyzując go nazwiskami twórców i cech ich systemu.

Prezentacja dziejów polskiej oświaty po 1863 r. nie uwzględnia bardzo istotnego zagadnienia, mianowicie Elementarza K. Promyka. Był to bowiem podręcznik, na którym wychowało się wiele pokoleń Polaków. Dopiero w 1910 r. ukazała się popularniejsza od niego publikacja M. Falskiego. Wymienione przez Autora wcześniejsze elementarze F. Krynickiego i F. S. Dmochowskiego były o wiele mniej znane.

Erudycja Autora jest dość wszechstronna. Ma jednak swoje preferencje. Oto starożytny perypatetyk, bardzo zresztą zasłużony w filozofii, znalazł u niego szczególne uznanie. Arystoteles bowiem pojawia się piętnaście razy na niepełnych dwóch stronach podręcznika (s. 27-28). Żadna inna osoba nie została w ten sposób wyróżniona w recenzowanej pozycji, biorąc pod uwagę objętość tekstu. Drugie miejsce ma J. H. Pestalozzi (28 razy na 5 stronach), zaś trzecie przypada J. J. Rousseau (23 razy na 6 stronach). Przyjęte przez Autora rozwiązanie dotyczące sposobu pisania podręcznika budzi pewne zastrzeżenia. Bardzo często ułatwiał sobie zadanie, cytując całe fragmenty syntez lub innych opracowań. Wydaje się, że takie rozwiązanie nie jest najlepszą metodą. Jako osoba odpowiedzialna za słowo powinien wykazać erudycję polegającą na uogólnieniach, które są ze 
swej natury konieczne. Żałować natomiast należy, że Autor prawie zupełnie pominął źródła pisane, dostępne w języku polskim.

Oddzielnego omówienia wymaga cytowanie długich fragmentów różnych syntez. Lepiej byłoby, gdyby Autor, streszczając i uogólniając passusy, włączył je w tekst podręcznika. Świadczyłoby to pozytywnie o jego umiejętnościach interpretacyjnych i syntetycznych. Nie jest również obowiązkiem piszącego podręcznik szczegółowo cytować wykorzystane pozycje. Oceniany podręcznik zawiera ich zbyt dużo, co utrudnia skupienie uwagi na określonym zagadnieniu.

Podobnie w naturalny sposób uwagę czytelnika rozpraszają przypisy. Jest ich aż 494, a więc średnio 1,5 na stronę tekstu. Jak na podręcznik obejmujący całość dziejów wychowania to liczba znacząca. Pytanie, czy trzeba było użyć ich aż tylu? Zastanawia też swoista monokultura, która dotyczy zwłaszcza monograficznej pracy A. Winiarza. Jest ona cytowana $\mathrm{w}$ dwóch ciągach (przypisy 200-205, 207-230). Z jednej strony to dobrze, że Autor podręcznika dostrzegł najlepszą pracę w tym zakresie, ale należało sięgnąć także do innych tytułów. Podobne uwagi dotyczą syntezy R. Wroczyńskiego i autorów włoskich. Wprawdzie są to podręczniki do dziejów oświaty i wychowania, lecz częste odnoszenie się do ich treści, nie stanowi najlepszej legitymacji dla piszącego, który powinien wiedzieć, że niezbędny jest umiar i reprezentatywny udział różnych (zwłaszcza monograficznych) pozycji.

Wnikliwa analiza tekstu ocenianego podręcznika, przeprowadzona z uwzględnieniem różnych porównań, uprawnia do sformułowania krytycznej opinii. Biorąc pod uwagę fakty, ich następstwo i skutki dochodzi się do wniosku, że podręcznik wymaga jeszcze wielu poprawek merytoryczno-metodycznych. Zawiera on bowiem różnego rodzaju błędy i nieścisłości, które dla przejrzystości uszeregowałem w następujących grupach:

1. Bibliografia - podział na 5 części jest jasny i nie budzi wątpliwości. Zdarzają się drobne błędy lub niekonsekwencje w zapisie. I tak Encyklopedia pedagogiczna XXI wie$k u$ zapisywana jest numeracją rzymską i arabską (s. 353-354) lub bez numeru tomu (s. 354). Kolejność nazwiska imienia (s. 358) T. Kukołowicz inna niż pozostałych redaktorów, brak numeru tomu przy artykule E. Karcz (s. 353). Przypis 156 (s. 146) - brak imienia drugiej osoby. W przypisie 103 zamiast „cechy” powinno być „cech” (zob. s. 353) i zamiast dywizu między nazwiskami powinien być przecinek (s. 353).

2. Błędna lub niedokładna argumentacja - Autor pisze (s. 55-56), że pierwsza szkoła katedralna powstała około roku 1000 w Poznaniu wraz z utworzeniem tam biskupstwa. Tymczasem biskupstwo to utworzono w 968 r. Cytując Arystotelesa (s. 27) Autor zamiast „rozumu” podał sztukę wymowy. Czy zatem jedno pojęcie jest równoznaczne z drugim? Korekty wymagają zdania: „Pierwszą szkołę otwarli (sic!) w Warszawie w 1658 r. Z czasem powstały szkoły w Rzeszowie (1658) ...” (s. 99). O ile pierwsze może ewentualnie pozostać bez zmiany, o tyle drugie należało zacząć od: „W tym samym roku powstała szkoła w Rzeszowie..." i dalej wymieniać inne z podaniem dat. Co najmniej dziwne wydaje się zaliczenie przez Autora kuli, sześcianu i walca do figur. To wiedza z klasy 4 szkoły podstawowej!. Elbląg (s. 111) w latach 1642-1648 należał do Polski. Stanisław Estreicher (s. 300) był profesorem historii ustroju i prawa UJ, zaś jego ojciec Karol Estreicher (s. 224) nie był językoznawcą. Forma i kolor (s. 163) nie jest właściwym przeciwstawie- 
niem jedności i wielości. Gdy powstało Towarzystwo do Ksiąg Elementarnych (s. 143) I. Potocki był pisarzem wielkim litewskim. Wcześniej jest mowa o Towarzystwie do Ksiąg Elementarnych niż o KEN (s. 145), pytanie dlaczego?. Jeśli wymienia się imiona fundatorów uniwersytetów (s. 69), to konsekwentnie powinno się przy Salamance uwzględnić Ferdynanda III Świętego (1217-1252). Dla Polaków (s. 196) Fryderyk August był księciem a nie królem. Dévaud w czasie pobytu w Jenie (1905 r.) mógł spotkać się tylko z jednym z wymienionych pedagogów (s. 261), mianowicie z W. Reinem (1847-1929), bowiem T. Ziller zmarł w 1882 r., zaś Stoy w 1885 r. Użyte określenie nie odpowiada więc faktom. Rein urodził się sześć lat po śmierci Herbarta, a więc nie mógł być jego bezpośrednim uczniem. Trudno zrozumieć dlaczego Autor zmienił napis na Pomniku Grunwaldzkim w Krakowie (s. 220), zamiast „Praojcom” podał „Ojcom”. Czy to lepiej służy wychowaniu patriotycznemu? Duchowni (s. 67) dzielą się na świeckich i zakonnych. Jeśli pisze się, że kolegium jezuickie (s. 96) obejmowało 5- lub 6-klasowy kurs, to rodzi się pytanie, ile lat trwało nauczanie poszczególnych przedmiotów w klasie 6, skoro zostało podane, iż klasa 5-letnia obejmowała 3 klasy gramatyki, jedną poetyki i jedną retoryki.

3. Błędnie dzielone wyrazy na stronach: 53 - Va-ison; 239 - Grunda-xiom; 284 Fo-ucauld.

4. Podane błędne daty. Prawidłowymi datami są: s. 50 - sobór w Chalcedonie 451 r.; s. 56 - bp Odrowąż zmarł w 1229 r.; s. 68 - sobór laterański III 1179 r.; s. 78 - zdobycie Konstantynopola przez Turków 1453 r.; s. 213 - Aniela Szycówna (1869-1921); s. 226 - Alfred Binet (1857-1911); s. 226 - Ellen Key (1849-1926); s. 300 - 6 listopada 1939 r.; s. 353 - Korczak Janusz (Henryk Goldszmit) (1878-1942).

5. Błędny zapis w języku lacińskim. Właściwy zapis jest następujący: s. 33 - Graecia; s. 36 - ludi magister; s. 39 - paedagogorum; s. 55 - Gothorum; s. 61 - Mettensium; s. 80 - mores; s. 83 - auctores; Moriae; s. 85 - Commentariolum; s. 89 - adolescentium; s. 90 - aperiendis; s. 130 - Gynaeceum; s. 137-139 - Philanthropinum; s. 348 - Gravissimum; s. 111 - Ianua.

6. Błędnie podane nazwiska. Właściwe brzmią: s. 20 - Pindar, Teognis z Megary; s. 59 - Zalaszowski; s. 203-204 - Dmochowski; s. 204 - Papłoński; s. 211 - Comte... John Stuart Mill..., Buckle; s. 212 - Aleksander Głowacki (Bolesław Prus); s. 216 - Józef Godecki; s. 224 - Courtenay; s. 232 - Mutermilchowa. Jest już utrwalona tradycją praktyka, która nakazuje prezentację danego nazwiska w pierwszym miejscu występowania (pełne imiona lub ich skróty i ewentualnie inne dane). W przypadku Kasjodora (s. 49, 54) jest inaczej.

7. Błędnie podane nazwy miejscowości, nazwiska, niewłaściwie użyte różne określenia oraz inne uchybienia:

a) wlaściwy zapis miejscowości brzmi: s. 89 - Königsberg (Królewiec, Kaliningrad); s. 91 - Goldberg (Złotoryja), s. 48, 140 - Lyon; s. 69, 72 - Montpellier; s. 90 Liège; s. 110 - Přerov; s. 112 - Sárospatak; s. 143 - Dederkały; s. 230 - Baltimore; s. 280 - Bar-sur-Loup, Vence.

b) występujące błędy w formie „przeciwieństw”: s. 28 - Isokrates i s. 30 - Izokrates; s. 35 - Kwintylian (ok. 35-100) i s. 38 Kwintylian (39-95); s. 35 - rhetor i s. 37 rethorica; s. 49 - Kasjodor (ok. 485-580) i s. 55 - Kasjodor (ok. 490-ok. 483); s. 81 - 
Liège i s. 90 - Liége; s. 82 - Vittorino i Wiktoryn; s. 110 - Fulnek i Fulnéck; 121 - Sain - Cyran i 123 - Saint - Cyran; 137 - Bassedow, Basedow i s. 138 - Basedow, Bassedow; s. 232 - Szkoła i społeczeństwo i Szkoła a społeczeństwo; s. s. 245 - Sokołowska Dzioba i s. 353 - Sokołowska-Dzioba; s. 248 - pour l'Éducation i s. 258 - pour l'École.

c) stylistyka: pozostawia wiele do życzenia. Przykładem jest 66 zdań (s. 233-238), w których słowo „doświadczenie” z wariantami fleksyjnymi występuje 43 razy. (Częściej więc niż 3 razy w dwóch zdaniach). To bezpośrednia droga do tautologii. Kilka akapitów (s. 38, 103, 199) zaczyna się od zwrotu „z kolei”, inne (s. 70, 89, 106, 126, 168, 248) mają swoje miejsce wewnątrz akapitu. Wydaje się, że ten frazes można zastąpić słowami (,zaś”, „,natomiast”). W tekście podręcznika znajduje się ponad 10 zdań, gdzie następne zdanie zaczyna się tym samym słowem, którym kończyło poprzednie. Nie należy to do mistrzostwa stylistycznego. Język bowiem jest na tyle bogaty, że umożliwia wykorzystywanie form zastępczych (np. zaimki i inne). Niefortunne jest także używanie tych samych wyrazów, które kończą jeden akapit i rozpoczynają nowy (s. 22, 154, 247). Zwykle bowiem ten odrębny fragment tekstu ma pewne nowe elementy treści. Tu tego nie widać. Nie jest to najlepsza prezentacja umiejętności Autora.

d) „internet składniowy”: jeśli w danym zdaniu występuje wyraz „w” trzy lub więcej razy, wówczas mamy sytuację ,,internetu składniowego”, ale nie tylko. Każdy inny wyraz, który występuje częściej niż trzy lub więcej razy otrzymuje takie samo określenie. Zdania, które należą do tej kategorii z wyrazem „w” znajdują się na stronach: 14, 239, 219, 195 oraz inne wyrazy na następujących stronach: (po 3) 12, 14, 14, 14, 16, 24, 34, 42, 49, 49, 49, 77, 79, 81, 115, 117, 176, 177, 192, 192, 193, 194, 200, 218; (ро 4) 69, 112, 181, 193, 220, 284, 285; (po 5) 21, 48, 102, 183.

c) niefortunne wyrażenia: s. 16 - wojskowo-żołnierskie; s. 17 - wojskowo-militarny, obywatel-żołnierz; s. 27 - potencjalne możliwości; s. 37 - szermowanie; s. 37 i 171 uciekanie się do; s. 40 - czy są cnoty teogonalne?; s. 41 - pierwotnie zachowując; s. 62 - nie były (...) którzy byli (...); s. 79 - mecenat (...) ogarniający; s. 105 - zarówno jeżeli chodzi o; s. 120 - akcentowanie górowania rozumu; s. 131 - program kulturowy s. 132 - wymuszanie (projektowanie); s. 156 - elementarna szkoła ludowa; s. 164 - harmonia przeciwieństw; s. 167 - je odwołując się; s. 169 - muszących podejmować... podjęcia; s. 167 - praktyczna nauka stosowana; s. 171 - Castellino da Castello do; s. 175 Działalności wychowawcza; s. 176 - marł; s. 177 - cetera; s. 181 - etyczno-moralny; s. 182 - rzeczywistość wychowania; s. 199 - ostały się; nędza panując na wsi; s. 200 zaniżono; s. 207 - wyrażała... wyrażające; s. 222 - zaniżone programy; zaniżonych... niżej; s. 226 - emblematyczna autorka; s. 278-279 - zadań tej instytucja; s. 304 - borykały się; s. 312 - Szkolnictwa Wyższy; s. 348 - dwutomowego działa; s. 355 - wychowawczegow. Chrześcijaństwo.

W kontekście wskazanych błędów i uchybień rodzi się zasadnicze pytanie: w jakim stopniu recenzowany podręcznik może spełniać funkcje podręcznika? Przytoczone zaś dane niech stanowią punkt wyjścia do dyskusji nad optymalizacją podręcznika historii wychowania.

Longum est educare et scribere.

Tadeusz Ostrowski 